\title{
Risk Analysis of Microfinance Conversion Based on ISO 31000 PT. Bank BRI Syariah. Tbk Aceh
}

\author{
Wa Ode Norlita ${ }^{1}$, Ayomi Dita Rarasati ${ }^{2}$ \\ 1Master Candidate of Department of Civil Engineering, University of Indonesia, Indonesia \\ ${ }^{2}$ Lecturer at Department of Civil Engineering, University of Indonesia, Indonesia
}

\begin{abstract}
Aceh government issued Aceh Qanun No. 11 of 2018 about Sharia Financial Institutions, which demands that all financial contracts in Aceh adhere to Sharia principles. This regulation has an impact on the Aceh region's financial business. PT Bank BRI Tbk Aceh has decided to conversion entire financing and funding portfolio to one of its sharia-compliant subsidiaries, PT Bank BRI Syariah Tbk. microfinance portfolio is bigger than other segments. By constructing a risk analysis based on ISO 31000, this study assesses the business risk associated with converting PT Bank BRI Syariah Tbk's microfinance segment in the Aceh region. The results indicate that twenty risks have been identified and evaluated. Risk can be classified into five broad categories: operational, reputational, strategic, credit, and compliance. The risk analysis results indicate that the risk is significant and requires immediate attention. Operational risk is associated with differences in data capacity, servers, the core banking system, and financing applications, whereas strategic risk is associated with differences in financial analysis, guarantee provisions, and regulations.
\end{abstract}

Keywords: ISO 31000, Qanun, Conversion, Risk Management

This is an open access article under the CC-BY-NC license.

\section{INTRODUCTION}

Aceh Province is the only province in Indonesia that has its own laws and regulations based on Islamic law called Qanun. Qanun no.11 of 2018 explains that when this Qanun comes into force, financial institutions operating in Aceh are obliged to adjust it no later than three years since this Qanun was promulgated. PT Bank BRI Tbk in the Aceh region has decided to convert its entire financing and funding portfolio to one of its sharia-based subsidiaries, PT Bank BRI Syariah Tbk amounting to Rp 11 trillion, where the micro segment has a larger portion (Rp5.77 trillion) than the retail segment, SME and consumers(Rp5.23 trillion).

Studies show that the ISO 31000 standard for risk management has the potential to be developed into a highly-adopted and impactful body of knowledge and standard of practice for the project risk management community (Olechowski, Oehmen, Seering, \& Ben-Daya, 2016). Further studies revealed that so far the Bank has used Bassel so that each risk is managed independently and not integrated, but by implementing ISO 31000 Rural Bank X the risk management can be carried out as a whole within the company (Darmawijaya, T.M.A.A., 2014).

How is the implementation of risk management based on ISO 31000 in the microfinance conversion PT Bank BRI Syariah Tbk? Considering that the risk management application implemented by banks is based on the Basel Accord and POJK, the researchers developed a risk analysis based on ISO 31000 in order to provide a new perspective and perception of business process risks in the conversion process of banking financing.

\section{LITERATURE REVIEW}

The ISO 31000 standard is intended to help organizations to manage in a systematic and comprehensive manner diverse types of risk by offering a universal framework to assist the organization to integrate risk management into its overall management system (ISO, 2009). The problem that arises is not when the management framework is implemented but is determined by its use by the organization (Lalonde, C. and Boiral, 0., 2012). 
RSF Conference Series: Business, Management and Social Sciences Vol. 1 (5), 125-134

Risk Analysis of Microfinance Conversion Based on ISO 31000 PT. Bank BRI Syariah. Tbk Aceh

Wa Ode Norlita, Ayomi Dita Rarasati

Risk management is generally grouped based on the industry in which risk management is applied (SNI ISO, 2018). In practice, risk management cannot be seen only from a grouping perspective for overall risk management, so more than one perspective is needed. The application of ISO 31000 in the banking sector can find out what risks are faced, and the appropriate actions that must be taken in dealing with the risks that arise (Darmawijaya, T.M.A.A., 2014).

\subsection{Banking Risk Management}

Risk management in banking in Indonesia is standardized by the Basel Accord II, a global accord reached at Basel by the world's central banks (Yushita, 2008). Bank Indonesia Regulation (PBI) No. 5/8/PBI/2003 issued May 19, 2003 about the Implementation of Risk Management for Islamic Commercial Banks and Sharia Business Units specifies the application of Basel II principles in Indonesia. Bank Indonesia Regulation Number 13/23/PBI/2011 regulates the types of risks that Islamic banks face, including credit, market, liquidity, operational, legal, reputation, strategic, compliance, return and investment.

\subsection{ISO 31000 Based Risk Management}

The risk management process involves the systematic application of policies, procedures and practices to the activities of communicating and consulting, establishing the context and assessing, treating, monitoring, reviewing, recording and reporting risk (ISO 31000, 2018). This process is illustrated in Figure 1.

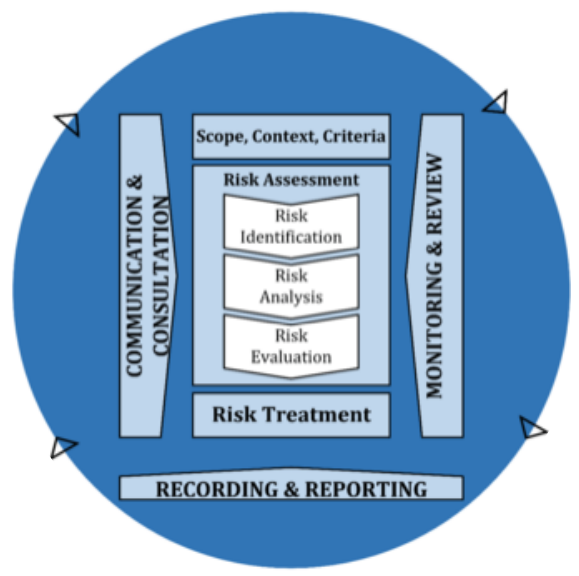

Figure 1. Risk Management Process ISO 31000:2018

(Source:ISO 31000:2018)

\section{RESEARCH METHODOLOGY}

This research use a qualitative paradigm in conjunction with a case study methodology or approach. Case study research is intended to delve deeply into the background of an issue, the conditions surrounding it, and the position of an ongoing event. A case study is a method for examining, explaining, or interpreting a situation in its natural setting, without the participation of a third party (Gunawan, 2017).

\subsection{Data analysis method}

The research was conducted at PT Bank BRI Syariah Tbk in the Aceh region. The risk assessment carried out in this research is based on the Risk Control Self-Assessment using the ISO 31000:2018 framework. Researchers develop risk analysis based on ISO 31000 in the banking sector.

\subsection{Data Source}

Primary and secondary data were analyzed in this study. The primary data for this study came straight from four expert interviews. While secondary data was gathered from books, journals, Bank Indonesia regulations, the financial services authority $(\mathrm{OJK})$ law, and the Consultative Assembly's Qanun.

\section{RESULTS AND DISCUSSION}

1.5. BRI Syariah Business Process Risk Management Based on ISO 31000

○ Risk Identification 
RSF Conference Series: Business, Management and Social Sciences Vol. 1 (5), 126-134

Risk Analysis of Microfinance Conversion Based on ISO 31000 PT. Bank BRI Syariah. Tbk Aceh

Wa Ode Norlita, Ayomi Dita Rarasati

It is known that there are 20 main risks and they are classified as banking risks based on the findings of interviews and documentation. The following are the main risks, which are categorized by the risk code "R":

Table 2. Main Risk Categories

\begin{tabular}{|c|c|c|}
\hline Risk Code & Main Risk & Banking Risk Category \\
\hline R1 & Increase in collectability & \multirow[t]{8}{*}{ Operational } \\
\hline R2 & work culture & \\
\hline R3 & Excess/ deficiency human resources & \\
\hline R4 & HR welfare differences & \\
\hline R5 & Many contract documents & \\
\hline R6 & Socialization \& internal training & \\
\hline R7 & Differences in data capacity, server, core banking & \\
\hline R8 & $\begin{array}{l}\text { Internal application features are rudimentary and } \\
\text { limited }\end{array}$ & \\
\hline R9 & Limited plafond & \multirow[t]{4}{*}{ Reputation } \\
\hline R10 & Business processes take longer & \\
\hline R11 & External socialization & \\
\hline R12 & Higher margin & \\
\hline R13 & HR target calculation & \multirow[t]{4}{*}{ Strategic } \\
\hline R14 & Product portfolio bookkeeping & \\
\hline R15 & Does not accommodate take over financing & \\
\hline R16 & Financial analysis, guarantee terms, policies & \\
\hline R17 & Customers in arrears & \multirow[t]{3}{*}{ Credit } \\
\hline R18 & Insurance terms & \\
\hline R19 & Customer monitoring tools & \\
\hline R20 & Defect of contract & Compliance \\
\hline
\end{tabular}

o Risk Analysis

a) Likehood and Consequence Analysis

The parameters used to assess the likelihood and consequence rating are to develop the customer service and teller assessment parameters at PT Bank BRI Syariah Tbk which are contained in the Risk and Control Self-Assessment Operational Report for September 2020 and the Financial Services Authority circular letter No.14/SE0JK.03/2017 concerning Commercial Bank Soundness Rating.

Table 3. Likelihood Rating Criteria

\begin{tabular}{lllll}
\hline Likehood Rating & Criteria & Probability & Probability (\%) & Frequency \\
\hline 1 & Very Low & Almost Never Happens & $0-10 \%$ & $\leq 1 \mathrm{x}$ per year \\
\hline 2 & Low & Rare & $>10 \%-20 \%$ & $\leq 2 \mathrm{x}$ per year \\
\hline 3 & Moderate & Occasionally & $>20 \%-50 \%$ & $\leq 4$ x per year \\
\hline 4 & High & Often & $>50 \%-70 \%$ & $\leq 6 \mathrm{x}$ per year \\
\hline 5 & Very High & Almost Definitely Happening & $>70 \%$ & $>6$ x per year \\
\hline
\end{tabular}

Table 4. Consequence Rating Criteria

\begin{tabular}{lllll}
$\begin{array}{l}\text { Cons. } \\
\text { Rating }\end{array}$ & Criteria & $\begin{array}{l}\text { Impact Proses } \\
\text { Bisnis }\end{array}$ & Financial Loss & Reputational \\
\hline 1 & Very Low & Not interefere & $<8,62$ Billion & $\begin{array}{l}\text { Very Minimal or Very Low } \\
\text { Negative Reporting }\end{array}$ \\
\hline 2 & Low & Slightly hindered & $\begin{array}{l}17,24-43,1 \\
\text { Billion }\end{array}$ & $\begin{array}{l}\text { Negative News Tend to Grow or } \\
\text { Low }\end{array}$ \\
\hline 3 & Moderate & Interfere & $\begin{array}{l}43,1-86,2 \\
\text { Billion }\end{array}$ & $\begin{array}{l}\text { Widespread or Fairly High } \\
\text { Negative News }\end{array}$ \\
\hline
\end{tabular}


RSF Conference Series: Business, Management and Social Sciences Vol. 1 (5), 125-134

Risk Analysis of Microfinance Conversion Based on ISO 31000 PT. Bank BRI Syariah. Tbk Aceh Wa Ode Norlita, Ayomi Dita Rarasati

\begin{tabular}{lllll}
\hline 4 & High & $\begin{array}{l}\text { Inhibiting certain } \\
\text { sections }\end{array}$ & $\begin{array}{l}86,2-258,6 \\
\text { Billion }\end{array}$ & $\begin{array}{l}\text { Very Wide or High Negative } \\
\text { Reports }\end{array}$ \\
\hline 5 & Very & $\begin{array}{l}\text { Inhibits and disrupts } \\
\text { the whole process }\end{array}$ & 258,6 Billion & $\begin{array}{l}\text { Loss of trust and/or regulator } \\
\text { reprimand }\end{array}$ \\
\hline
\end{tabular}

Table 5. Likelihood and Consequence Rating Assessment

\begin{tabular}{llcc}
\hline Risk Code & Possible impact & $\begin{array}{c}\text { Likehood } \\
\text { Rating }\end{array}$ & $\begin{array}{l}\text { Impact } \\
\text { Rating }\end{array}$ \\
\hline R1 & Increased CKPN costs & 2 & 3 \\
\hline R2 & Decreased HR motivation & 2 & 2 \\
\hline R3 & Decreased work unit productivity & 3 & 3 \\
\hline R4 & High HR turnover & 3 & 2 \\
\hline R5 & Longer process business & 1 & 2 \\
\hline R6 & $\begin{array}{l}\text { Not familiar with the core banking system, Competence related } \\
\text { to sharia aspects has not met }\end{array}$ & 3 & 2 \\
\hline R7 & $\begin{array}{l}\text { system failure, customers are not maintained, the system is not } \\
\text { stable }\end{array}$ & 5 & 4 \\
\hline R8 & The process stages are not effective & 4 & 3 \\
\hline R9 & $\begin{array}{l}\text { Customers cannot be converted, customer financing volume } \\
\text { decreases }\end{array}$ & 1 & 3 \\
\hline R10 & Longer process business SLA & 1 & 2 \\
\hline R11 & The customer is not informed of the conversion process & 3 & 3 \\
\hline R12 & Refuse the financing conversion & 2 & 3 \\
\hline R13 & The volume of customer financing decreases & 2 & 2 \\
\hline R14 & The special target for conversion customers not achieve & 1 & 2 \\
\hline R15 & Decreased financing volume & 2 & 2 \\
\hline R16 & Customers switch to other financial institutions & 5 & 4 \\
\hline R17 & The decrease in the volume of financing & 1 & 2 \\
\hline R18 & Increase in collectability & 2 & 2 \\
\hline R19 & Use of non-partner life insurance & 2 & 3 \\
\hline R20 & Customer accounts are not maintained & 1 & 3 \\
\hline & & & \\
\hline
\end{tabular}

b) Inherent Risk Analysis

Referring to SE No.14/SE0JK.03/2017 concerning the Assessment of Commercial Bank Soundness Levels and the level of assessment on customer service and tellers at PT Bank BRIsyariah Tbk contained in the Risk and Control Self Assessment Operational Report document for September 2020, the level in Inherent risk assessment in this study is divided into five levels of risk value, namely very low(VL), Low(L), Moderate(M), High(H), and Very High(VH). The inherent risk analysis is used to ascertain the risks associated with activities prior to their control

Table 6. Inherent Risk Map

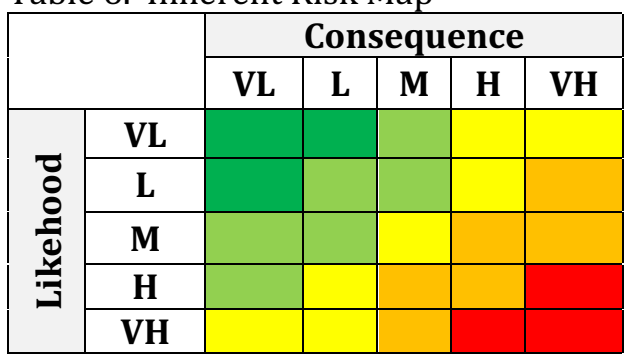

Table 7. Inherent Risk Rating Criteria

\begin{tabular}{lll}
\hline $\begin{array}{l}\text { Inherent } \\
\text { Risk Rating }\end{array}$ & Criteria & Probability Affected by Loss \\
\hline 1 & Very Low & Very low \\
\hline 2 & Low & Low \\
3 & Moderate & Quite high \\
\hline
\end{tabular}


RSF Conference Series: Business, Management and Social Sciences Vol. 1 (5), 126-134

Risk Analysis of Microfinance Conversion Based on ISO 31000 PT. Bank BRI Syariah. Tbk Aceh

Wa Ode Norlita, Ayomi Dita Rarasati

\begin{tabular}{lll}
\hline 4 & High & High \\
5 & Very High & Very high \\
\hline
\end{tabular}

Table 8.

Inherent Risk Rating Result

\begin{tabular}{|c|c|c|c|}
\hline Risk Code & Likehood Rating & Impact Rating & Inherent Risk Rating \\
\hline R7 & 5 & 4 & 5 \\
\hline$\overline{\mathrm{R} 16}$ & 5 & 4 & \\
\hline R8 & 4 & 3 & 4 \\
\hline R3 & 3 & 3 & 3 \\
\hline R11 & 3 & 3 & \\
\hline R1 & 2 & 3 & 2 \\
\hline $\mathrm{R} 2$ & 2 & 2 & \\
\hline $\mathrm{R} 4$ & 3 & 2 & \\
\hline R6 & 3 & 2 & \\
\hline R9 & 1 & 3 & \\
\hline $\mathrm{R} 12$ & 2 & 3 & \\
\hline$\overline{\mathrm{R} 13}$ & 2 & 2 & \\
\hline R15 & 2 & 2 & \\
\hline R18 & 2 & 2 & \\
\hline R19 & 2 & 3 & \\
\hline $\mathrm{R} 20$ & 1 & 3 & \\
\hline$\overline{\mathrm{R} 5}$ & 1 & 2 & 1 \\
\hline R10 & 1 & 2 & \\
\hline R14 & 1 & 2 & \\
\hline $\mathrm{R} 17$ & 1 & 2 & \\
\hline
\end{tabular}

Based on table 7, the risks of concern are those that fall into the moderate, high, and very high categories. The risks included in the Very High criteria are 2 risks (R7, R16), those included in the High criteria are 1 risk (R8), and those included in the Moderate criteria are 2 risks (R13, R11).

c) Effectiveness Risk Control Analysis

The parameters used are the development of research conducted by McCrea, D. (2019). The following are the details of the parameters used to determine the effectiveness risk control rating:

Table 9. Forms of Risk Control in Activities

\begin{tabular}{lll}
\hline Control Rating 1 & Control Form I & Description \\
\hline 1 & Preventive & Controls that are carried out before problems arise. \\
\hline 2 & Detective & $\begin{array}{l}\text { controls are implemented where there has been a } \\
\text { problem. }\end{array}$ \\
\hline 3 & Corrective & $\begin{array}{l}\text { Controls are carried out to improve conditions if there } \\
\text { is a problem that causes the risk of not achieving the } \\
\text { objectives }\end{array}$ \\
\hline Table 10. Forms of Treatment Risk Control & \\
\hline Control Rating 2 & Control Form II & Description Control Activities \\
\hline 2 & Automatic & Fully automated \\
\hline 3 & Semi Automatic & Automatically and human abiliteis \\
\hline
\end{tabular}

Table 11. Effectiveness Risk Control Map

\begin{tabular}{|c|c|c|c|}
\hline & \multicolumn{3}{|c|}{ Control 2 } \\
\hline Control 1 & Automatic & Semi Automatic & Manual \\
\hline Preventive & & & \\
\hline
\end{tabular}


RSF Conference Series: Business, Management and Social Sciences Vol. 1 (5), 125-134

Risk Analysis of Microfinance Conversion Based on ISO 31000 PT. Bank BRI Syariah. Tbk Aceh

\begin{tabular}{|l|l|l|}
\hline Detective & & \\
\hline Corrective & & \\
\hline
\end{tabular}

Table 12. Control Effectiveness Level Criteria

\begin{tabular}{lll}
\hline $\begin{array}{l}\text { Control } \\
\text { Rating }\end{array}$ & Effectivenes & \multicolumn{1}{c}{ Description } \\
1 & Very Sufficient & Sufficient to control,implemented consistently with a high degree of automatior \\
\hline 2 & Sufficient & $\begin{array}{l}\text { Sufficient to partially control,implemented consistently with a partial degree of } \\
\text { automation }\end{array}$ \\
\hline 3 & Insufficient & $\begin{array}{l}\text { It is not enough to control, the implementation is inconsistent, the whole thing } \\
\text { still manual }\end{array}$ \\
\hline
\end{tabular}

The effectiveness of control is classified into two categories, namely control actions and control treatment. The following are the findings from the study's analysis of risk control effectiveness:

Table 13. Risk Control Effectiveness Analysis Results

\begin{tabular}{llll}
\hline Risk Code & Control Rating 1 & Control Rating 2 & Effectivenes Rating \\
\hline R7 & 3 & 3 \\
\hline R8 & 3 & 2 \\
\hline R1 & 2 & 3 \\
\hline R3 & 2 & 3 \\
\hline R17 & 2 & 3 \\
\hline R19 & 2 & 3 \\
\hline R2 & 1 & 3 \\
\hline R4 & 1 & 3 \\
\hline R5 & 1 & 3 \\
\hline R6 & 1 & 3 \\
\hline R9 & 1 & 3 \\
\hline R10 & 1 & 3 \\
\hline R11 & 1 & 3 \\
\hline R12 & 1 & 3 \\
\hline R13 & 1 & 3 \\
\hline R14 & 1 & 3 \\
\hline R15 & 1 & 3 \\
\hline R16 & 1 & 3 \\
\hline R18 & 1 & 3 \\
\hline R20 & 1 & 3 \\
\hline
\end{tabular}

The results of the analysis show that of the 20 risks, 6 are included in the criteria of not being sufficient and 14 other risks being sufficient. The value of this effectiveness is strongly influenced by the control carried out before/during/after the occurrence of the risk. As in the R7 and R8 risks associated with the system, where problems have occurred, the differences in system and application features. Because all business processes are carried out with the system, so improvements are carried out in parallel. The risk that is included in the sufficient category is caused by the risk control that is carried out before the problem arises.

d) Risk Residual Analysis

The parameters used are the development of research conducted by McCrea, D. (2019). The following are the details of the parameters used to determine the risk residual rating:

Table 14. Residual Risk Map

\begin{tabular}{|c|c|c|c|}
\hline Residual Risk & \multicolumn{3}{|c|}{ Effectiveness } \\
\hline Inherent Risk & 1 & 2 & 3 \\
\hline 1 & & & \\
\hline 2 & & & \\
\hline
\end{tabular}


RSF Conference Series: Business, Management and Social Sciences Vol. 1 (5), 126-134 Risk Analysis of Microfinance Conversion Based on ISO 31000 PT. Bank BRI Syariah. Tbk Aceh Wa Ode Norlita, Ayomi Dita Rarasati

\begin{tabular}{|l|l|l|l|}
\hline $\mathbf{3}$ & & & \\
\hline $\mathbf{4}$ & & & \\
\hline $\mathbf{5}$ & & & \\
\hline
\end{tabular}

Table 15. Residual Risk Criteria

\begin{tabular}{lll}
\hline $\begin{array}{l}\text { Residual } \\
\text { Risk Rating }\end{array}$ & Criteria & Control Description \\
\hline 1 & Low & Very adequate, residual risk faced is very low \\
\hline 2 & Moderate & Sufficiently adequate, residual risk faced is quite high \\
\hline 3 & High & Inadequate, residual risk faced is very high \\
\hline
\end{tabular}

Residual risk analysis is used to assess the risks that remain after risk mitigation/control measures have been implemented.

Table 16. Risk Residual Analysis Results

\begin{tabular}{|c|c|c|c|}
\hline Risk Code & Inherent Risk Rating & Effectivenes Rating & Residual Risk Rating \\
\hline R7 & 5 & 3 & \multirow[t]{3}{*}{3} \\
\hline R8 & 4 & 3 & \\
\hline R16 & 5 & 2 & \\
\hline $\mathrm{R} 1$ & 2 & 3 & \multirow[t]{13}{*}{2} \\
\hline $\mathrm{R} 2$ & 2 & 2 & \\
\hline R3 & 3 & 3 & \\
\hline $\mathrm{R} 4$ & 2 & 2 & \\
\hline R6 & 2 & 2 & \\
\hline R9 & 2 & 2 & \\
\hline R11 & 3 & 2 & \\
\hline $\mathrm{R} 12$ & 2 & 2 & \\
\hline R13 & 2 & 2 & \\
\hline R15 & 2 & 2 & \\
\hline R18 & 2 & 2 & \\
\hline R19 & 2 & 3 & \\
\hline $\mathrm{R} 20$ & 2 & 2 & \\
\hline $\mathrm{R} 5$ & 1 & 2 & \multirow[t]{4}{*}{1} \\
\hline R10 & 1 & 2 & \\
\hline R14 & 1 & 2 & \\
\hline $\mathrm{R} 17$ & 1 & 3 & \\
\hline
\end{tabular}

From the results of the risk residual analysis, it is known that the risks that are classified as high are in the operational $(\mathrm{R} 7, \mathrm{R} 8)$ and strategic (R16) categories. This shows that the control is inadequate and the risks faced by BRIsyariah are very high in the microfinance conversion process.

○ Risk Evaluation

The risk value used in risk evaluation is the value/rating obtained from the risk residual analysis. Priorities of risks is determined using the following categories:

Table 17. Risk Priority Parameters

\begin{tabular}{lll}
\hline $\begin{array}{l}\text { Residual Risk } \\
\text { Rating }\end{array}$ & Priority & Description \\
\hline 1 & Low priority & Can be delayed to repair, the impact is small \\
\hline 2 & Moderate priority & $\begin{array}{l}\text { Must be repaired, can be delayed, impact is moderately } \\
\text { disturbed }\end{array}$ \\
\hline 3 & Priority & $\begin{array}{l}\text { It must be repaired as early as possible, the impact will be } \\
\text { greatly disrupted }\end{array}$ \\
\hline
\end{tabular}


Risk evaluation aims to determine the priority of risks and the response that will be taken when a risk occurs. The following table summarizes the evaluation findings for each risk:

Table 18. Risk Evaluation Results

\begin{tabular}{lll}
\hline Priority & Residual Risk Rating & Risk Code \\
\hline Priority & 3 & R7,R8,R16 \\
\hline Moderate Priority & 2 & R1,R2,R3,R4,R6,R9,R11, \\
& & R12,R13,R15,R18,R19,R20 \\
\hline Low Priority & 1 & R5,R10,R14,R17 \\
\hline
\end{tabular}

The priority risks are operational risk $(\mathrm{R} 7, \mathrm{R} 8)$ and strategic risk (R16). This risk must be handled as early as possible because it has a large impact on the conversion of BRIsyariah microfinance. Risks that are categorized as moderate priority must also be corrected but can be postponed because they can interfere with the conversion process of microfinance but at a moderate level. Meanwhile, the risk that is classified as low priority can be postponed for repair because the impact that occurs when this risk appears is relatively small.

o Risk Treatment

To deal with the risks that arise in microfinance conversion activities, each risk must have its own risk management. Risk management activities carried out by BRIS based on SNI ISO 31000 are reduced by carrying out certain activities in order to improve risk control capabilities.

Table 19. Risk Treatment

\begin{tabular}{|c|c|c|}
\hline Priority & $\begin{array}{l}\text { Risk } \\
\text { Code }\end{array}$ & Activity Treatment \\
\hline \multirow[t]{3}{*}{ Priority } & R7 & Portfolio migration manually and systemically \\
\hline & R8 & Maximize the development of application features \\
\hline & R16 & Updating terms, policies, conditions \\
\hline \multirow[t]{13}{*}{ Moderate Priority } & R1 & $\begin{array}{l}\text { Ensure the readiness of systems, human resources, and work units to } \\
\text { manage micro portfolio }\end{array}$ \\
\hline & $\mathrm{R} 2$ & Equalization and socialization of work culture \\
\hline & R3 & $\begin{array}{l}\text { Provides conditional options for employees who convert, reject } \\
\text { conversion, or resign }\end{array}$ \\
\hline & $\mathrm{R} 4$ & Update HR prosperity policy \\
\hline & R6 & $\begin{array}{l}\text { Basic sharia banking training for BRI HR and refreshing basic sharia } \\
\text { banking material for BRIS HR }\end{array}$ \\
\hline & R9 & Updating the maximum financing plafond policy \\
\hline & R11 & Conversion and product socialization to external \\
\hline & $\mathrm{R} 12$ & Evaluation and dissemination of rate margin and other costs \\
\hline & R13 & Determination of KPI parameters in detail \\
\hline & R15 & Development of a take-over pattern of financing in the system \\
\hline & R18 & $\begin{array}{l}\text { Letters to all branch offices and socialization regarding the guarantee } \\
\text { policy }\end{array}$ \\
\hline & R19 & Maximizing monitoring development in applications \\
\hline & $\mathrm{R} 20$ & Islamic banking basic training for $\mathrm{HR}$ \\
\hline \multirow[t]{4}{*}{ Low Priority } & R5 & Simplification of contracts according to sharia principles \\
\hline & R10 & Process business flow updates \\
\hline & R14 & Meeting with related groups for product portfolio register agreement \\
\hline & R17 & $\begin{array}{l}\text { post booking review of financing proposals that have been processed, } \\
\text { reminder to customers before the due date }\end{array}$ \\
\hline
\end{tabular}

Risk treatment is a form of mitigation that has been carried out and has gone through a discussion process with resource persons and experts in the relevant field. The results of the discussions carried out were 
RSF Conference Series: Business, Management and Social Sciences Vol. 1 (5), 126-134

Risk Analysis of Microfinance Conversion Based on ISO 31000 PT. Bank BRI Syariah. Tbk Aceh

Wa Ode Norlita, Ayomi Dita Rarasati

adjusted to the existing business processes and the needs in the microfinance conversion process so that the activities of each risk could be implemented.

\section{CONCLUSION}

According to the National Standardization Agency (2018), risk management is based on the industry in which risk management is applied. However, to see the overall risk cannot be seen only from the point of view of the grouping alone. Banking risk management has been regulated in Bank Indonesia Regulation (PBI) No.13/23/PBI/2011. However, it does not contain details about the risk assessment, but rather the measurement of Islamic banking risk in general.

In accordance with the statement of Lalonde, C and Boiral, O., (2012) that the effectiveness of ISO 31000 is determined by how it is used. The risk assessment in this study uses the ISO 31000:2018 framework. From the results of this study, it is known that there are 20 risks that have been evaluated and after being identified, the risks are categorized into 5 banking risks, namely operational, reputation, strategic, credit, and compliance.

The risks that are prioritized in the conversion of the microfinance business are operational risks, R7 (differences in data capacity, server, core banking), R8 (internal application features are rudimentary and limited) and strategic risk, R16 (financial analysis, guarantee terms, policies). Risks that are included in the priority category must be addressed as early as possible because they have a significant impact on the ongoing conversion process of the microfinance business.

\section{References}

Darmawijaya, T.M.A.A. (2014). Penerapan ISO 31000 Dalam Pengelolaan Risiko Pada Bank Perkreditan Rakyat (Studi Kasus Bank Perkreditan Rakyat X). Jurnal Administrasi Bisnis Universitas Katolik Parahiyangan 10(1), 17-32.

Gunawan, Imam. (2017). Metode Penelitian Kualitatif. Edisi Pertama. Cetakan Kelima. Jakarta:Bumi Aksara.

International Organization for Standardization (ISO). (2018). ISO 31000:2018 Risk managementGuidelines. Switzerland.

International Organization for Standardization (ISO). (2019). ISO 31000-Risk Management:Principles and Guidelines, Geneva, 2009.

Lalonde, C. and Boiral, O. (2012). Managing Risks Through ISO 31000: A Critical Analysis. Journal of Risk Management, 14(4), 272-300.

McCrea, David. (2019). Risk Management : The Continous Program Cycle. Paper presented at Washington Bankers Association Executive Development Program Audit and Compliance

Olechowski, A., Oahmen, J., Seering,W., Ben-Daya, M. (2016). The Professionalization of Risk Management : What Role Can The ISO 31000 Risk Management Principles Play. International Journal of Project Management, 34, 1568 - 1578.

Pemerintah Aceh. (2018). Qanun Aceh Nomor 11 Tahun 2018 Lembaga Keuangan Syari'ah. Lembaran Aceh Tahun 2019 Nomor 8. Banda Aceh.

Peraturan Bank Indonesia Nomor 13/23/PBI/2011 Tahun 2011 Penerapan Manajemen Risiko Bagi Bank Umum. 2 November 2011. Lembaran Negara Republik Indonesia Tahun 2011 Nomor 103 DPbS. Jakarta.

Peraturan Bank Indonesia Nomor 5/8.PBI/2003 Tahun 2003 Penerapan Manajemen Risiko Bagi Bank Umum Syariah Dan Unit Usaha Syariah. 19 Mei 2003. Lembaran Negara Republik Indonesia Tahun 2003 Nomor 56 DPNP. 
RSF Conference Series: Business, Management and Social Sciences Vol. 1 (5), 125-134

Risk Analysis of Microfinance Conversion Based on ISO 31000 PT. Bank BRI Syariah. Tbk Aceh

Wa Ode Norlita, Ayomi Dita Rarasati

Qanun Aceh Nomor 11 Tahun 2018 Lembaga Keuangan Syar'iah. 31 Desember 2018. Lembaran Aceh Tahun 2019 Nomor 8. Banda Aceh

Risk and Control Self Assetment Operatonal Report PT Bank BRIsyariah Tbk. (2020). Jakarta : PT Bank BRIsyariah Tbk

Surat Edaran Otoritas Jasa Keuangan Nomor 14/SEOJK.03/2017 Penilaian Tingkat Kesehatan Bank Umum. 17 Maret 2017. Jakarta.

Vorst, C. R., Priyarsono, D.D., dan Budiman, A. (2018). Manajemen Risiko Berbasis SNI ISO 31000. Edisi Pertama. Cetakan Pertama. Badan Standarisasi Nasional. Jakarta.

Yushita, N.Y. (2008). Implementasi Risk Management Pada Industri Perbankan Nasional. Jurnal Pendidikan Akuntansi Indonesia, VI(I), 75-86. 